\title{
Stimulation of thermal stability of $\alpha$-amylase from Bacillus icheniformis ATCC 6346 by treating with cations
}

\author{
A .Vengadaramana ${ }^{1}$, S . Balakumar ${ }^{2}$ and V. Arasaratnam ${ }^{2}$ \\ ${ }^{1}$ Department of Botany, Faculty of Science, University of Jaffna, Sri Lanka. \\ ${ }^{2}$ Department of Biochemisty, Faculty of Medicine, University of Jaffna, Sri Lanka. \\ Accepted 06 June 2012
}

\begin{abstract}
$\alpha$-Amylases (1,4- $\alpha$-D-glucan glucanohydrolase; E.C.3.2.1.1) catalyze the cleavage of $\alpha$-1,4-glucosidic linkages in starch, glycogen, and various oligosaccharides. Thermostable $\alpha$-amylases from Bacillus species are of great industrial importance in the production of corn syrup or dextrose. In this study effect of different cations on the enhancement of stability of $\alpha$-amylase from Bacillus licheniformis ATCC 6346 was examined. Optimal activity of the enzyme was at $\mathrm{pH} 7.0$ and $85{ }^{\circ} \mathrm{C}$. $\alpha$-Amylase activity was strongly inhibited by $\mathrm{Cu}^{2+}, \mathrm{Hg}^{2+}$ and $\mathrm{Mn}^{2+}$ but less affected by $\mathrm{Mg}^{2+}$ and $\mathrm{Ba}^{2+} \cdot \mathrm{Ca}^{2+}$ and $\mathrm{Na}^{+}$stimulated the enzyme activity at $85^{\circ} \mathrm{C}$ and at $\mathrm{pH} 7.0$. Addition of $0.01 \mathrm{M} \mathrm{Na}^{+}$enhanced the enzyme stability from 1-33\% for $60 \mathrm{~min}$ at $85{ }^{\circ} \mathrm{C}$ and $\mathrm{pH} \mathrm{7.0.} \mathrm{With} 0.1 \mathrm{M} \mathrm{Na}^{+}, 100 \%$ of initial enzyme activity was retained for $150 \mathrm{~min}$ and $70 \mathrm{~min}$ at $60{ }^{\circ} \mathrm{C}$ and $70{ }^{\circ} \mathrm{C}$, respectively and $88 \%$ activity was retained at $80{ }^{\circ} \mathrm{C}$, at pH 7.0 for $60 \mathrm{~min}$. In the presence of $1 \mathrm{mM} \mathrm{Ca}^{2+}$, no loss of activity was observed in $60 \mathrm{~min}$, at $85^{\circ} \mathrm{C}$ and $\mathrm{pH} 7.0$. Combined addition of $1 \mathrm{mM} \mathrm{Ca}^{2+}$ and $0.1 \mathrm{M} \mathrm{Na}^{+}$, retained $17.3 \%$ of the enzyme activity for $180 \mathrm{~min}$. But the enzyme in the presence of $1 \mathrm{mM} \mathrm{Ca}^{2+}$ and $0.1 \mathrm{M} \mathrm{Na}^{+}$separately, lost its total activity in $120 \mathrm{~min}$ and $90 \mathrm{~min}$, respectively at $95{ }^{\circ} \mathrm{C}$ and $\mathrm{pH} 7.0$.
\end{abstract}

Key words: calcium, sodium, enzyme activity, enzyme stability, half life, starch

\section{INTRODUCTION}

Bacillus species produce a variety of extracellular enzymes, such as amylases, which have significant industrial importance (Cordeiro et al., 2003). Bacterial amylases are known to be more thermostable than fungal amylases (Eke and Oguntimehin, 1992). Amylases have attracted the world's enzyme market because of their wide application in starch based industries especially food, textile, paper, detergent and baking industries (Gregory and Woods, 1995). They represent $25 \%$ of the world's market of enzymes (Niehaus et al., 1999; Asgher et al., 2007). Most of the commercially produced amylases are of microbial origin (Pandey et al., 2000). The enzyme $\alpha$-Amylase (EC 3.2.1.1, 1,4$\alpha$-D glucanohydrolase, endoamylase) hydrolyses starch, glycogen and related polysaccharides by randomly cleaving internal $\alpha-1,4$-glucosidic linkages. Amylase activity has been shown to be influenced by temperature, $\mathrm{pH}$ and presence of some chemicals (Swain and Ray, 2007). All known $\alpha$-amylases have a conserved calcium binding site (Boel et al., 1990; Machius et al., 1998; Machius et al., 1995). The binding of $\mathrm{Ca}^{2+}$ ions has been shown to increase the $\alpha$-helical

*Corresponding author's email: vengad@jfn.ac.lk structure of $\alpha$-amylase leading to increased stability (Kim et al., 1991). Apart from calcium, other ions such as sodium and chloride have been implicated as allosteric activators of $\alpha$ amylases (Kim et al., 1991). Sodium ions rather than calcium ions have retained the structure and function of Amy K38, an $\alpha$-amylase from the Bacillus sp. strain KSM-K38 (Hagihara et al., 2001; Nonaka et al., 2003) and various other $\alpha$ amylases (Vihinen et al., 1990; Kobayashi et al., 1992). Calcium ions have been implicated in the mechanisms involving thermal inactivation of Bacillus $\alpha$-amylases, where it has been proposed that the first step involves the reversible dissociation of calcium ions from the native enzyme, followed by irreversible denaturation at high temperatures (Lecker et al., 1996; Tanaka et al., 2002). Almost all of the technical $\alpha$ amylases however need a certain amount of calcium ions in the application, because their thermostability depends on the presence of structural calcium ions (Chiang et al., 1979). Therefore, the objective of this study was to improve the thermostability of $\alpha$-amylase from Bacillus licheniformis ATCC 6346 by applying different cations. 


\section{MATERIALS AND METHODS}

Bacillus licheniformis ATCC 6346 from HeriotWatt University U.K was used in this study.

The nutrient agar medium used in the study contained ( $\mathrm{L}^{-}$) $25.0 \mathrm{~g}$ nutrient agar, $3.0 \mathrm{~g}$ soluble starch. The activation medium used in the study contained ( $\left.\mathrm{L}^{-}\right) 25.0 \mathrm{~g}$ nutrient broth, and $3.0 \mathrm{~g}$ soluble starch at $\mathrm{pH}$ 7.0. The fermentation medium contained ( $\left.\mathrm{L}^{-}\right) 4.0 \mathrm{~g}$ soluble starch, 5.0 $\mathrm{g}\left(\mathrm{NH}_{4}\right)_{2} \mathrm{SO}_{4}, 6$ g peptone; $0.01 \mathrm{~g} \mathrm{FeCl}_{3} ; 0.01 \mathrm{~g}$ $\mathrm{MgCl}_{2} \cdot 6 \mathrm{H}_{2} \mathrm{O} ; 0.01 \mathrm{~g} \quad \mathrm{CaCl}_{2} \cdot 2 \mathrm{H}_{2} \mathrm{O} ; 4.0 \mathrm{~g}$ of $\mathrm{KH}_{2} \mathrm{PO}_{4}$, and $7.5 \mathrm{~g}$ of $\mathrm{K}_{2} \mathrm{HPO}_{4}$ at $\mathrm{pH}$ 7.0.

A loopful of Bacillus licheniformis ATCC 6346 grown in nutrient agar slants with $0.3 \%$ soluble starch at $37{ }^{\circ} \mathrm{C}$ for $24 \mathrm{~h}$ was transferred to $10 \mathrm{ml}$ activation medium and incubated at 42 ${ }^{\circ} \mathrm{C}$ in a rotary shaker $(100 \mathrm{rpm})$ for $12 \mathrm{~h}$ and used as the inoculum. The fermentation medium was inoculated with $20 \%(\mathrm{v} / \mathrm{v})$ inoculum and the inoculated flasks were incubated for $48 \mathrm{~h}$ at 42 ${ }^{\circ} \mathrm{C}$ and spun at $100 \mathrm{rpm}$. The culture filtrate was used as the source of $\alpha$-amylase.

To determine the effect of temperature on the stability of $\alpha$-amylase, $\alpha$-amylase in $\mathrm{pH} 7.0$ buffer was pre-incubated at 75 and $85^{\circ} \mathrm{C}$ and the enzyme activity was monitored (Miller, 1959). The half-life of the enzyme was taken as the time taken for its activity to be reduced to half of the original activity.

\section{Effect of cations on the activity and stability of $\alpha$-amylase}

To partially purify the crude $\alpha$-amylase, to $10 \mathrm{ml}$ of the crude enzyme extract $2.91 \mathrm{~g}$ of solid ammonium sulphate was added to bring the concentration of ammonium sulphate to $50 \%$. The precipitate was allowed to settle and collected by centrifugation (refrigerated centrifuge, $3000 \mathrm{rpm}$ for $30 \mathrm{~min}$ at $4{ }^{\circ} \mathrm{C}$ ). The precipitate was dissolved in $2 \mathrm{ml}$ distilled water and dialyzed against distilled water. The dialyzed $\alpha$-amylase was used to study the effect of cations on the activity and stability of $\alpha$ amylase.

To determine the effect of $2 \mathrm{mM}$ cations such as $\mathrm{Ca}^{2+}, \mathrm{Ba}^{2+}, \mathrm{Mg}^{2+}, \mathrm{Mn}^{2+}, \mathrm{Na}^{+}, \mathrm{Hg}^{2+}$, and $\mathrm{Cu}^{2+}$ on the activity of $\alpha$-amylase produced by B. licheniformis ATCC 6346. Some cations and phosphate ions present in the spent medium were removed by ammonium sulphate precipitation and dialysis before using because $\mathrm{Ca}^{2+}, \mathrm{Ba}^{2+}$, $\mathrm{Mg}^{2+}$ and $\mathrm{Hg}^{2+}$ ions would precipitate with phosphate ions $\left(\mathrm{Ca}^{2+}, \mathrm{Mg}^{2+}, \mathrm{Na}^{+}, \mathrm{Hg}^{2+}\right.$ and $\mathrm{Ba}^{2+}$ in the form of chlorides and $2 \mathrm{mM} \mathrm{Cu}^{2+}$ and $\mathrm{Mn}^{2+}$ in the form of sulphate).

To determine the effect of $\mathrm{Na}^{+}$on the stability of $\alpha$-amylase, $\alpha$-amylase was incubated at $85{ }^{\circ} \mathrm{C}$ in $\mathrm{pH} 7.0$ buffer containing different concentrations of $\mathrm{Na}^{+}(0.05$ to $0.4 \mathrm{M})$ and the enzyme activity was monitored.

To determine the thermal stability of $\alpha$ amylase containing $\mathrm{Na}^{+}$at different temperatures, $\alpha$-amylase was pre-incubated at temperatures 60, 70, 80 and $85{ }^{\circ} \mathrm{C}$ in $\mathrm{pH} 7.0$ buffer containing $0.1 \mathrm{M} \mathrm{Na}^{+}$and the $\alpha$-amylase activity was monitored.

To determine the effect of $\mathrm{Ca}^{2+}$ on the stability of the enzyme, $\alpha$-amylase from Bacillus licheniformis ATCC 6346 was pre-incubated at $85{ }^{\circ} \mathrm{C}$ in $\mathrm{pH} 7.0$ buffer containing different concentrations of $\mathrm{Ca}^{2+}$ (1 to $0.05 \mathrm{mM}$ ) and the $\alpha$ amylase activity was monitored.

To determine the stability of $\alpha$-amylase in presence of both $\mathrm{Na}^{+}$and $\mathrm{Ca}^{2+}$, at different temperatures, $\alpha$-amylase was incubated in $\mathrm{pH}$ 7.0 buffer containing $0.1 \mathrm{M} \mathrm{Na}^{+}$and $1 \mathrm{mM} \mathrm{Ca}{ }^{2+}$ at temperatures 85,90 and $95{ }^{\circ} \mathrm{C}$ and the activity of $\alpha$-amylase was monitored.

\section{RESULTS}

Effect of temperature on the stability of $\alpha$ amylase

When the crude $\alpha$-amylase extract was preincubated at $85{ }^{\circ} \mathrm{C}$ it retained $60 \%$ of its original activity for $10 \mathrm{~min}$ and lost all its activity at 60 min (Fig. 1). When the crude $\alpha$-amylase was pre- incubated at $75{ }^{\circ} \mathrm{C}, 88 \%$ of its activity was retained for $10 \mathrm{~min}$ and $81 \%$ of its original activity for $60 \mathrm{~min}$. Thus, the stability of $\alpha$ amylase was longer at $75^{\circ} \mathrm{C}$ than at $85^{\circ} \mathrm{C}$.

Effect of cations on the activity of $\alpha$-amylase The effect of $2 \mathrm{mM} \mathrm{Ca}^{2+}, \mathrm{Ba}^{2+}, \mathrm{Mg}^{2+}, \mathrm{Mn}^{2+}, \mathrm{Na}^{+}$, $\mathrm{Hg}^{2+}$ and $\mathrm{Cu}^{2+}$ on $\alpha$-amylase activity are presented in Table 1 . In the presence of $\mathrm{Ca}^{2+}$ and $\mathrm{Na}^{+}$, the enzyme showed higher activity at $85{ }^{\circ} \mathrm{C}$ and $\mathrm{pH}$ 7.0. A slight inhibition in enzyme activity was produced by $\mathrm{Mg}^{2+}$ and $\mathrm{Ba}^{2+}$ and a stronger inhibition by $\mathrm{Cu}^{2+}, \mathrm{Mn}^{2+}$ and $\mathrm{Hg}^{2+}$ (Table 1).

Effect of $\mathrm{Na}^{+}$on the stability of $\alpha$-amylase When $\alpha$-amylase containing different concentrations of $\mathrm{Na}^{+}(0.05-0.4$ M) was incubated at $\mathrm{pH} 7.0$ and $85^{\circ} \mathrm{C}$, in the presence of all concentrations $\mathrm{Na}^{+}, \alpha$-amylase showed a higher stability than in the absence of $\mathrm{Na}^{+}$(Fig. 2 ). The enzyme in the presence of $0.1 \mathrm{M} \mathrm{Na}^{+}$ lost $67 \%$ of its initial activity in $60 \mathrm{~min}$ (Fig. 2). When $\alpha$-amylase was pre-incubated in the presence of $0.05,0.2,0.3,0.4 \mathrm{M}$ and in the absence of $\mathrm{Na}^{+}$, the enzyme activity was retained 
at $29.5,29.4,28,20.5$ and $0.0 \%$ respectively at $60 \mathrm{~min}$ (Fig. 2). Half-life of $\alpha$-amylase in the presence of $0.1 \mathrm{M} \mathrm{Na}^{+}$was 42.8 min while in the absence of $\mathrm{Na}^{+}$it was $13.8 \mathrm{~min}$ (Table 2). In the presence of $0.1 \mathrm{M} \mathrm{Na}^{+} \alpha$-amylase showed a 1.9 fold increase in half-life in comparison to $0.4 \mathrm{M}$ $\mathrm{Na}^{+}$(Table 2).
Stability of $\alpha$-amylase in the presence of $\mathrm{Na}^{+}$ at different temperatures

When $\alpha$-amylase was pre-incubated in the presence of $0.1 \mathrm{M} \mathrm{Na}^{+}$at $60{ }^{\circ} \mathrm{C}, 98 \%$ of its initial activity was retained for $120 \mathrm{~min}$. At 70, 80 and $85{ }^{\circ} \mathrm{C} ; 9,29$ and $96 \%$ of its initial activity was lost (Fig. 3) respectively at $120 \mathrm{~min}$ and $\mathrm{pH}$ 7.0. When the pre-incubation temperature was decreased from 85 to $60{ }^{\circ} \mathrm{C}$, half-life of $0.1 \mathrm{M}$ $\mathrm{Na}^{+}$containing $\alpha$-amylase was increased by 19.6 fold at $\mathrm{pH} 7.0$ (Table 3 ).

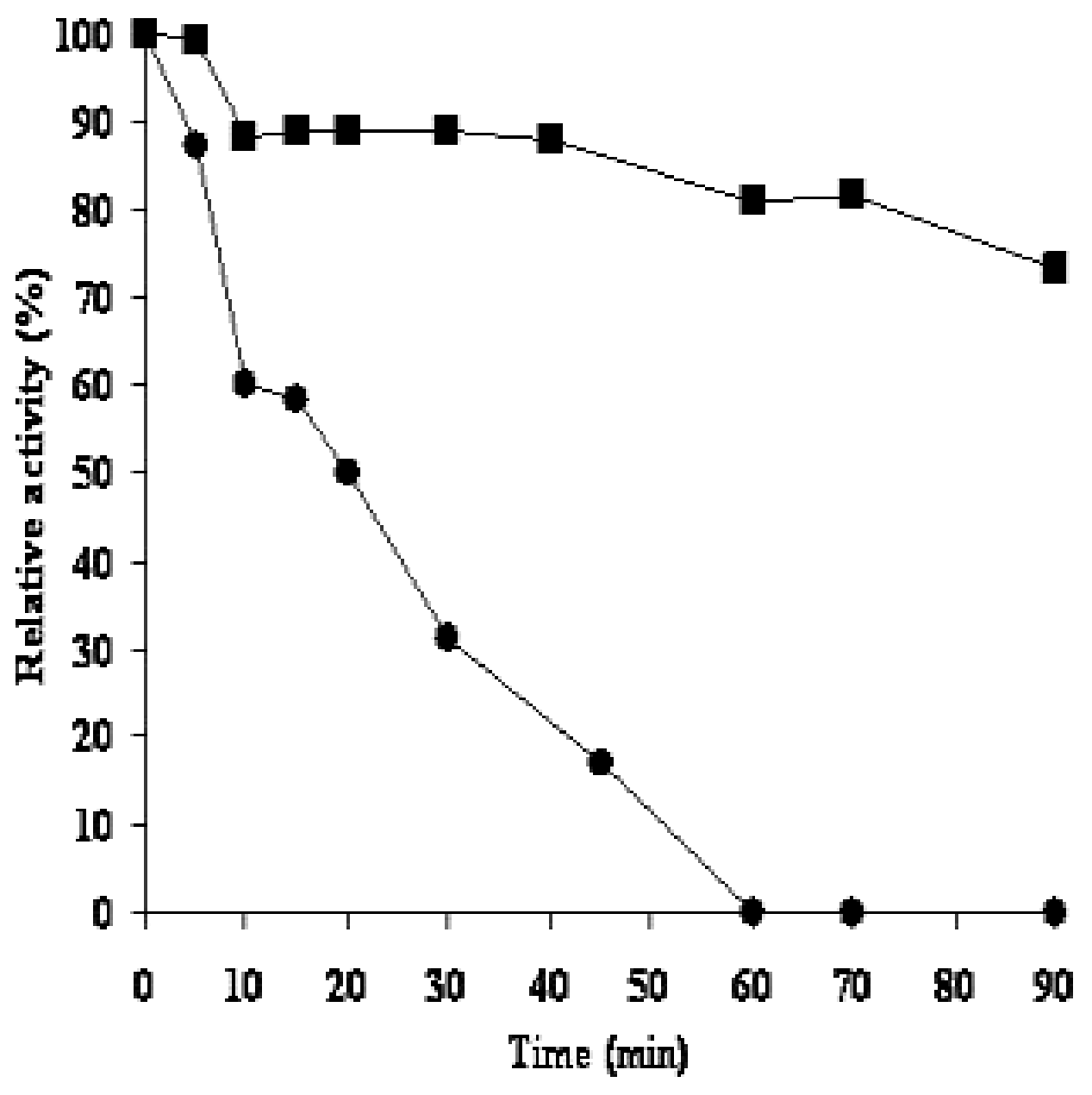

Figure 1. Stability of crude $\alpha$-amylase at $75{ }^{\circ} \mathrm{C}(\boldsymbol{\square})$ and $85{ }^{\circ} \mathrm{C}(\bullet), \alpha$-amylase activity was measured using $20 \mathrm{gL}^{-1}$ starch as substrate and incubating for $5 \mathrm{~min}$ at $\mathrm{pH}$ 7.0. 


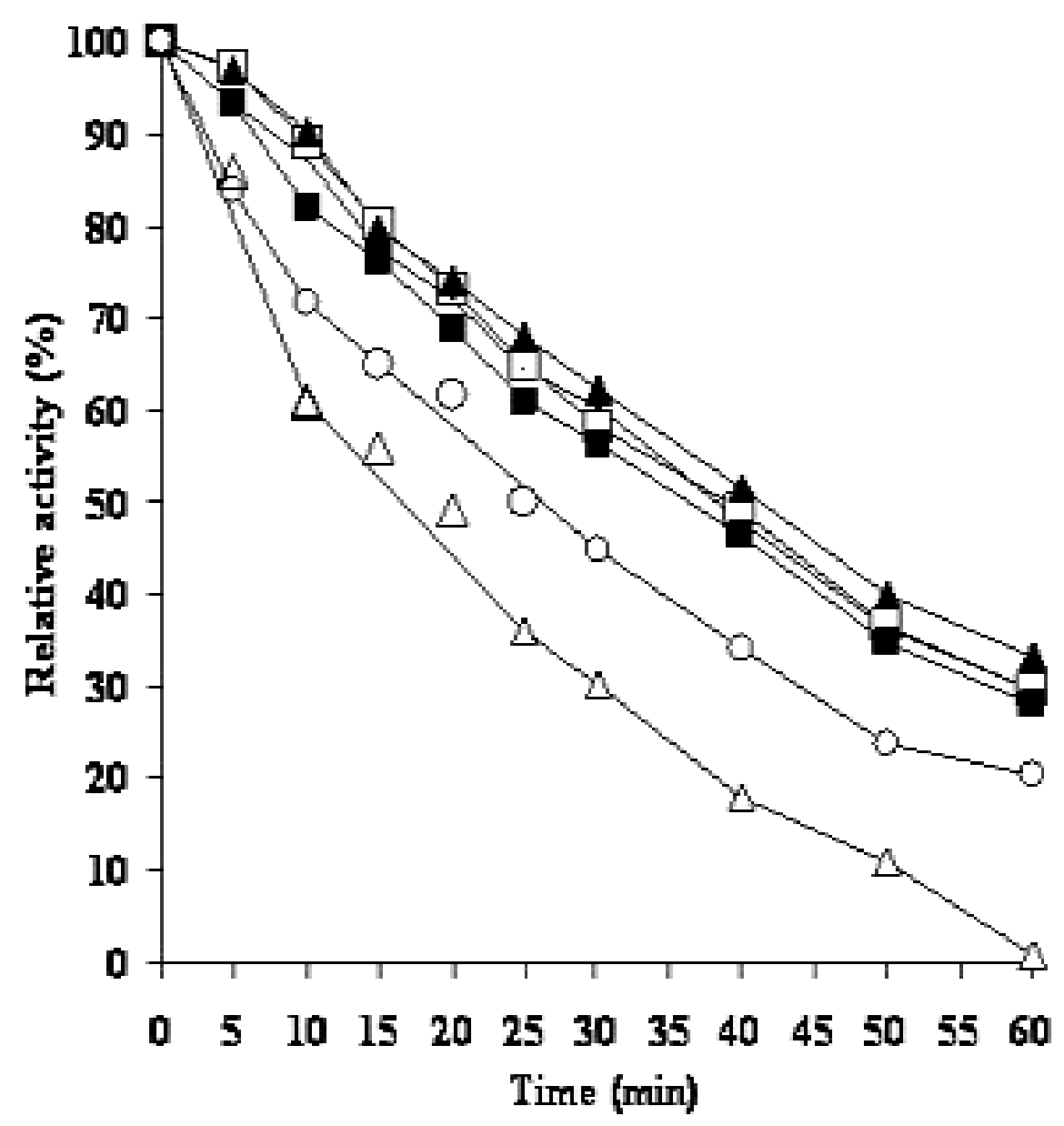

Figure 2. Effect of different concentrations of $\mathrm{Na}^{+} ; 0(\Delta) ; 0.05 \mathrm{M}(\square) ; 0.1 \mathrm{M}(\boldsymbol{\Delta}) ; 0.2 \mathrm{M}(\bullet) ; 0.3 \mathrm{M}(\boldsymbol{\square})$ and $0.4 \mathrm{M} \mathrm{Na}^{+}(\mathrm{O})$, on the stability of $\alpha$-amylase from Bacillus licheniformis ATCC $6346 . \alpha$-amylase activity was measured at $85{ }^{\circ} \mathrm{C}$ using $20 \mathrm{gL}^{-1}$ starch as substrate and incubating for $5 \mathrm{~min} \mathrm{pH}$ at 7.0.

Table 1. Effect of different cations $(2 \mathrm{mM})$ on the activity of $\alpha$-amylase produced by Bacillus licheniformis ATCC 6346. $\alpha$-amylase activity was determined at $85{ }^{\circ} \mathrm{C}$ and $\mathrm{pH} 7.0$ using $20 \mathrm{~g}$ $\mathrm{L}^{-1}$ starch as substrate by incubating for at $5 \mathrm{~min}$.

\begin{tabular}{lc}
\hline $\begin{array}{l}\text { Cations } \\
(\mathbf{2} \mathbf{~} \mathbf{M})\end{array}$ & $\begin{array}{l}\text { Relative } \alpha \text {-amylase } \\
\text { activity }(\boldsymbol{\%})\end{array}$ \\
\hline Control* $^{*}$ & 100 \\
$\mathrm{Ca}^{2+}$ & 108 \\
$\mathrm{Ba}^{2+}$ & 93 \\
$\mathrm{Mg}^{2+}$ & 97 \\
$\mathrm{Mn}^{2+}$ & 39 \\
$\mathrm{Na}^{+}$ & 103 \\
$\mathrm{Hg}^{2+}$ & 0 \\
$\mathrm{Cu}^{2+}$ & 0.75 \\
\hline
\end{tabular}

* Buffered $\alpha$-amylase solution
Table 2. Half-life of $\alpha$-amylase in the presence of different concentrations of $\mathrm{Na}^{+}$at $85{ }^{\circ} \mathrm{C}$ and $\mathrm{pH} 7.0$.

\begin{tabular}{lc}
\hline $\mathbf{N a}^{+}(\mathbf{M})$ & Half-life (min) \\
\hline & \\
0 & 13.8 \\
0.05 & 38.4 \\
0.1 & 42.8 \\
0.2 & 41.2 \\
0.3 & 36.3 \\
0.4 & 22.2 \\
\hline
\end{tabular}




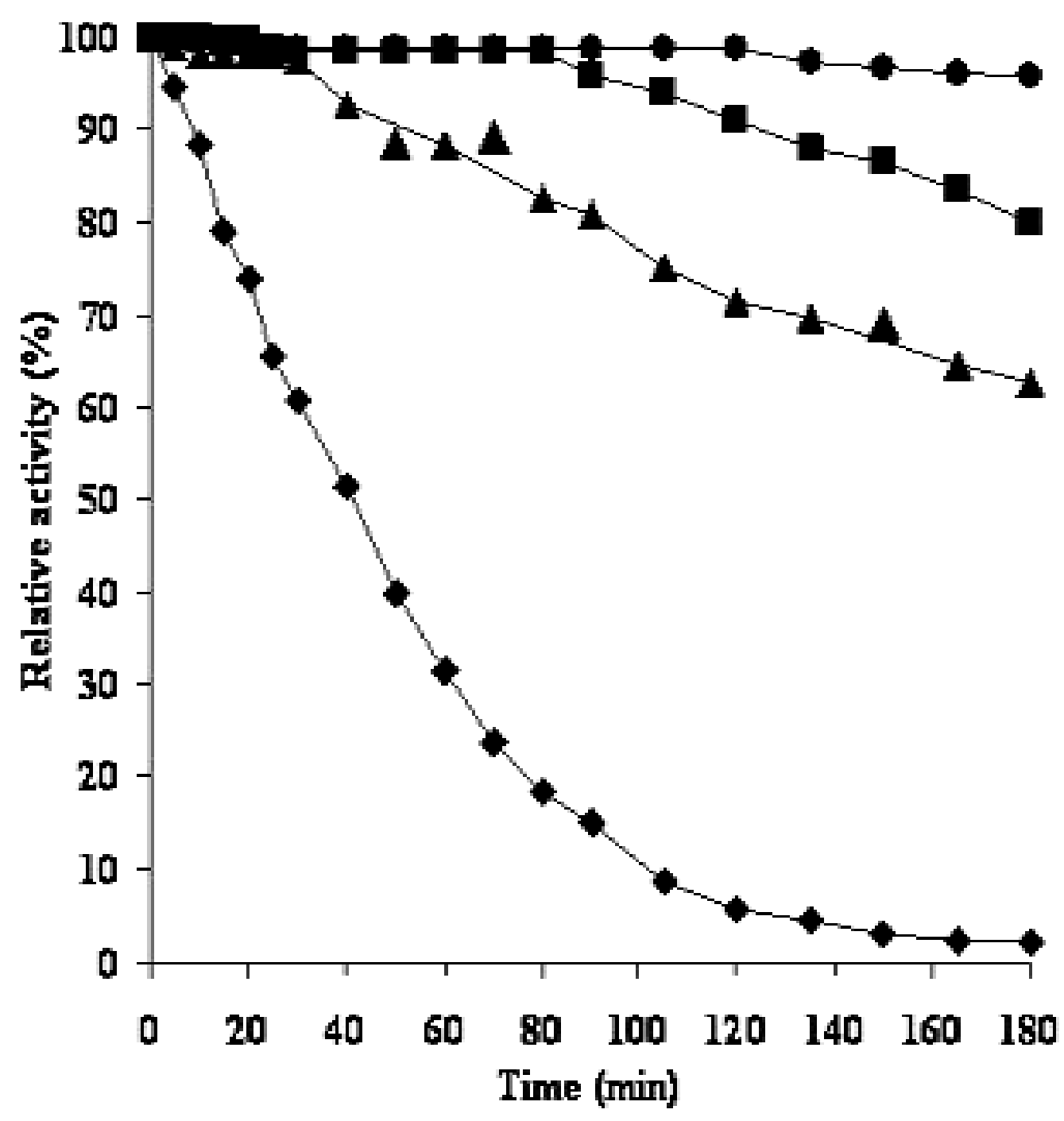

Figure 3. Stability of $0.1 \mathrm{M} \mathrm{Na}^{+}$containing $\alpha$-amylase from Bacillus licheniformis ATCC 6346, at $60(\bullet)$; $70(\boldsymbol{\square}) ; 80(\boldsymbol{\Delta})$ and $85{ }^{\circ} \mathrm{C}(\diamond)$. $\alpha$-amylase activity was measured using $20 \mathrm{~g} \mathrm{~L}^{-1}$ starch as substrate and incubating for $5 \mathrm{~min}$ at $\mathrm{pH} 7.0$.

Table 3. Half-life of $\alpha$-amylase in the presence of $0.1 \mathrm{M} \mathrm{Na}^{+}$at different temperatures at $\mathrm{pH}$ 7.0.

\begin{tabular}{ll}
\hline $\begin{array}{l}\text { Temperature } \\
\left({ }^{\mathbf{0}} \mathbf{C}\right)\end{array}$ & $\begin{array}{l}\text { Half-life of } \boldsymbol{\alpha} \text {-amylase } \\
(\mathbf{m i n})\end{array}$ \\
\hline 60 & 838.9 \\
70 & 428.4 \\
80 & 249.4 \\
85 & 42.8 \\
\hline
\end{tabular}

Table 4. Half-life of $\alpha$-amylase in the presence of different concentrations of $\mathrm{Ca}^{2+}$ at $85{ }^{\circ} \mathrm{C}$ and $\mathrm{pH} 7.0$.

\begin{tabular}{lc}
\hline $\mathbf{C a}^{2+}(\mathbf{m M})$ & Half-life (min) \\
\hline 0 & 26.9 \\
0.05 & 275.5 \\
0.1 & 433.2 \\
0.5 & 1443.5 \\
0.7 & 1750.3 \\
1.0 & 1782.0 \\
\hline
\end{tabular}


Effect of $\mathrm{Ca}^{2+}$ on the stability of $\alpha$-amylase In the presence of 0.7 and $0.05 \mathrm{mM} \mathrm{Ca}^{2+}$ at 85 ${ }^{\circ} \mathrm{C}$, the enzyme retained 96.3 and $82.0 \%$ relative activity (Fig. 4) of its initial activity at $60 \mathrm{~min}$. In the absence of $\mathrm{Ca}^{2+}$ the enzyme retained $30 \%$ of its initial activity at $60 \mathrm{~min}$ at $85^{\circ} \mathrm{C}$ and $\mathrm{pH}$ 7.0. In the presence of $1.0 \mathrm{mM} \mathrm{Ca}{ }^{2+} \alpha$-amylase showed 6.5 fold increase in half-life when compared to that in the presence of $0.05 \mathrm{mM}$ $\mathrm{Ca}^{2+}$ at $85^{\circ} \mathrm{C}$ and $\mathrm{pH} 7.0$ (Table 4).

Effect of Stability of $\mathrm{Na}^{+}$and $\mathrm{Ca}^{2+}$ containing $\alpha$-amylase at different temperatures

In the previous experiment when $\mathrm{Na}^{+}$and $\mathrm{Ca}^{2+}$ were added separately, the stability of $\alpha$-amylase was improved. Therefore, the combined effect of the two ions on $\alpha$-amylase stability at different temperatures was studied. $\alpha$-amylase containing $0.1 \mathrm{M} \mathrm{Na}^{+}$and $1 \mathrm{mM} \mathrm{Ca}^{2+}$, was pre-incubated at different temperatures $\left(85,90\right.$ and $\left.95{ }^{\circ} \mathrm{C}\right)$. At $180 \mathrm{~min}$ in the presence of both $0.1 \mathrm{M} \mathrm{Na}^{+}$and 1
$\mathrm{mM} \mathrm{Ca}{ }^{2+}$, the enzyme retained 94 and $64 \%$ (Fig. $5)$ of the initial activity at 85 and $90{ }^{\circ} \mathrm{C}$ respectively. $\alpha$-amylase retained 77 and $23 \%$ of its initial activity at $180 \mathrm{~min}$ in the presence of 1 $\mathrm{mM} \mathrm{Ca}{ }^{2+}$ at 85 and $90{ }^{\circ} \mathrm{C}$ respectively. However, the enzyme lost all of its activity at 210 and 120 min (data not shown in the figure) in the presence of $0.1 \mathrm{M} \mathrm{Na}^{+}$respectively at 85 and 90 ${ }^{\circ} \mathrm{C}$. Half-life of $\alpha$-amylase in the presence of either $0.1 \mathrm{M} \mathrm{Na}^{+}$or $1 \mathrm{mM} \mathrm{Ca}{ }^{2+}$ or both, decreased with increasing temperature (Table 5). When $\alpha$-amylase was incubated at 90 and $95{ }^{\circ} \mathrm{C}$ in the presence of $0.1 \mathrm{M} \mathrm{Na}^{+}$and $1 \mathrm{mM} \mathrm{Ca}^{2+}$, the enzyme showed respectively 8.7 and 32 fold decrease in half-life when compared at $85^{\circ} \mathrm{C}$. In the presence of $0.1 \mathrm{M} \mathrm{Na}^{+}$and $1 \mathrm{mM} \mathrm{Ca}^{2+}$, at $180 \mathrm{~min}, \alpha$-amylase lost $83 \%$ of its initial activity at $95{ }^{\circ} \mathrm{C}$ (Fig. 5). However, in the presence of either $1 \mathrm{mMCa}^{2+}$ or $0.1 \mathrm{M} \mathrm{Na}^{+}$, the enzyme lost its total activity at 120 and $90 \mathrm{~min}$ respectively at $\mathrm{pH}$ 7.0.

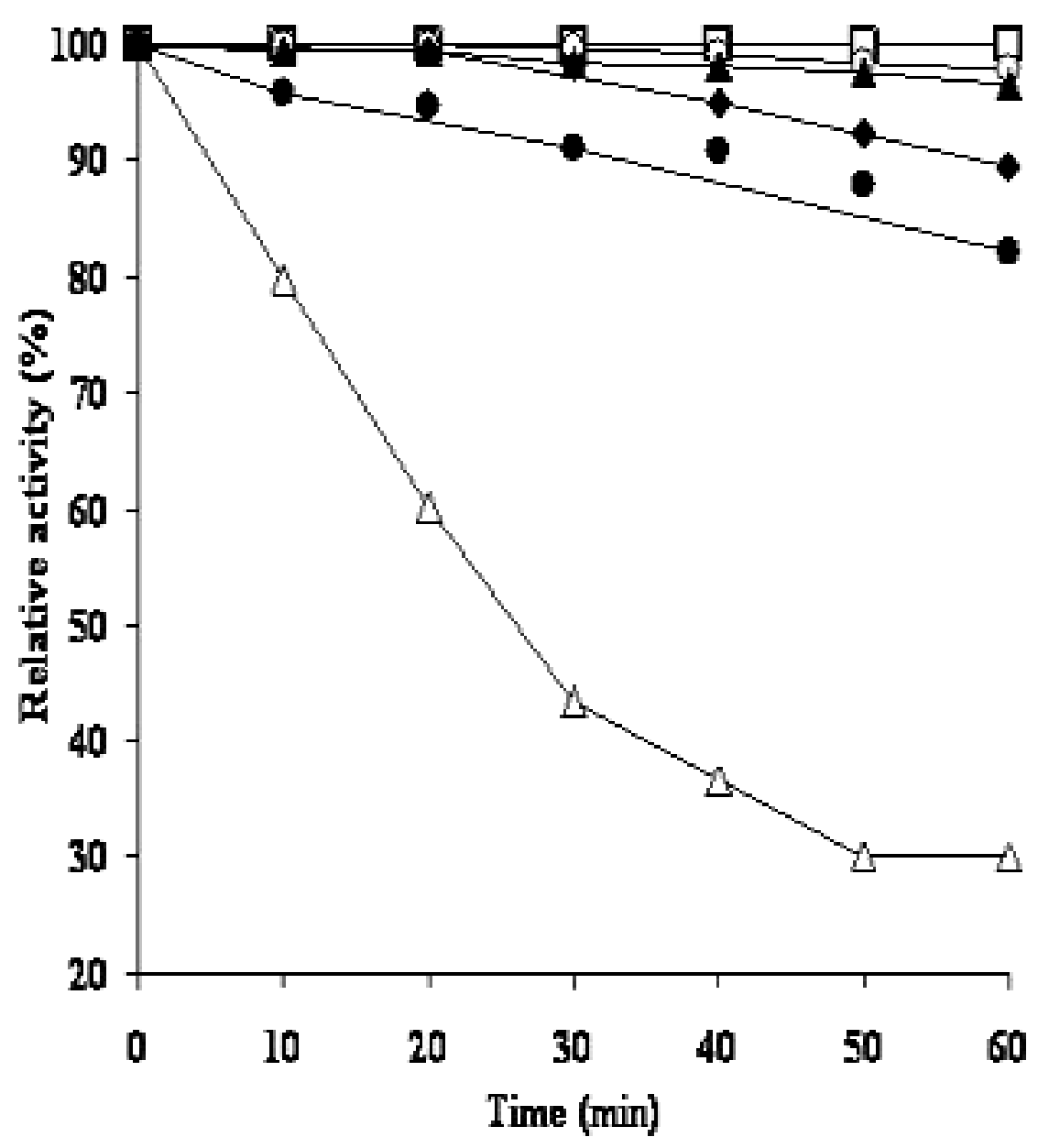

Figure 4. Effect of different concentration of $\mathrm{Ca}^{++}: 0(\Delta), 0.05(\bullet), 0.1(\bullet), 0.5(\boldsymbol{\Delta}), 0.7(\mathrm{O})$ and $1 \mathrm{mM}(\square)$, on the stability of $\alpha$-amylase from Bacillus licheniformis ATCC 6346. $\alpha$-amylase activity was measured at $85{ }^{\circ} \mathrm{C}$ using $20 \mathrm{~g} \mathrm{~L}^{-1}$ starch as substrate and incubating for $5 \mathrm{~min}$ at $\mathrm{pH}$ 7.0. 
Table 5. Half-life of $\alpha$-amylase in the presence of either $0.1 \mathrm{M} \mathrm{Na}^{+}$or $1 \mathrm{mM} \mathrm{Ca}^{2+}$ or both cations at different temperatures at $\mathrm{pH}$ 7.0.

\begin{tabular}{|c|c|c|c|}
\hline \multirow[t]{2}{*}{$\begin{array}{l}\text { Temperature } \\
\left({ }^{\circ} \mathrm{C}\right)\end{array}$} & \multicolumn{3}{|c|}{$\begin{array}{l}\text { Half-life of } \alpha \text {-amylase } \\
\text { (min) }\end{array}$} \\
\hline & $0.1 \mathrm{M} \mathrm{Na}^{+}$ & $1 \mathrm{mM} \mathrm{Ca}^{2+}$ & $0.1 \mathrm{M} \mathrm{Na}^{+}$and $1 \mathrm{mM} \mathrm{Ca}{ }^{2+}$ \\
\hline 85 & 42.8 & 1782.0 & 2421.2 \\
\hline 90 & 17.7 & 93.0 & 279.5 \\
\hline 95 & 10.6 & 23.4 & 75.5 \\
\hline
\end{tabular}

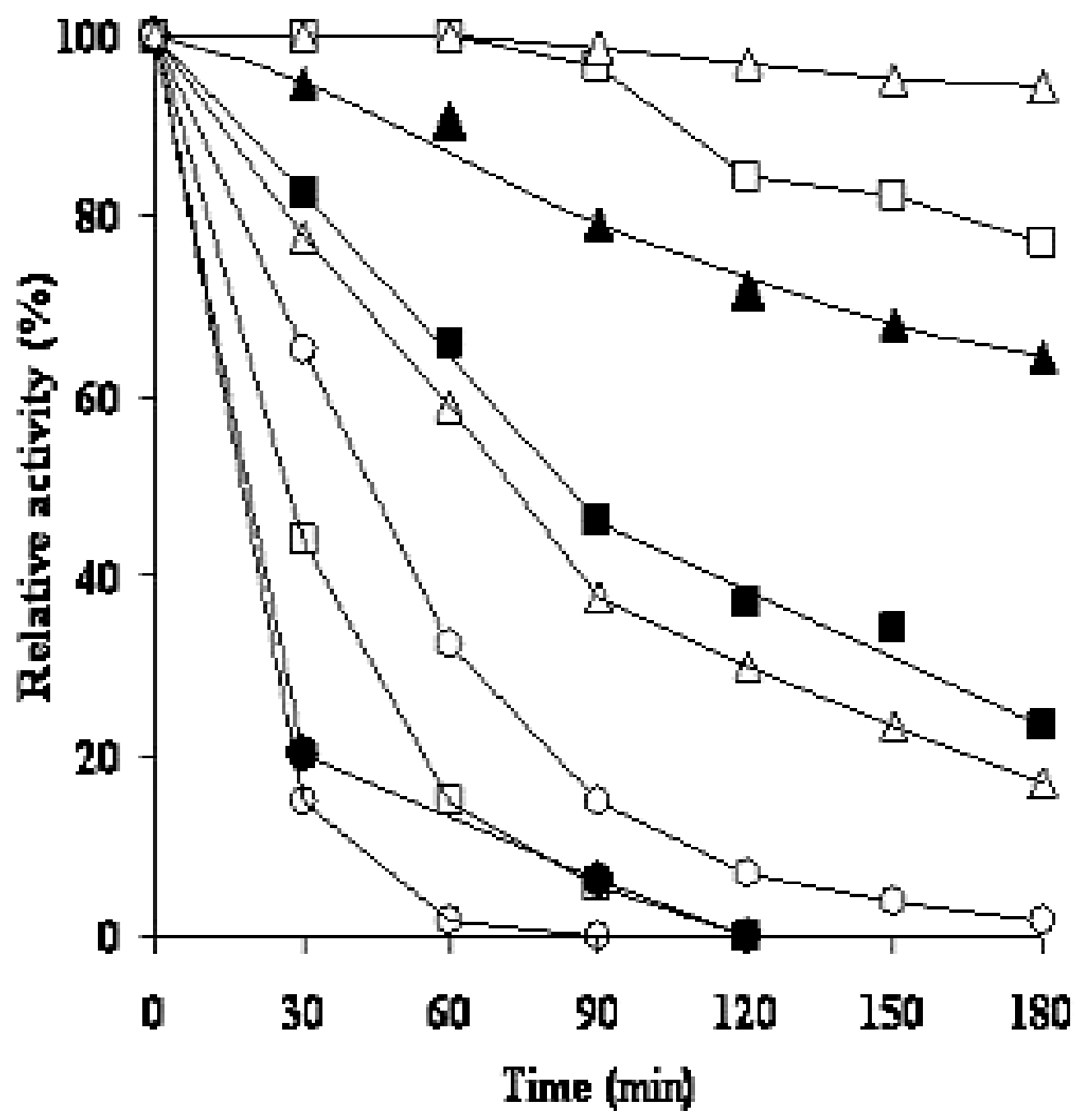

Figure 5. Stability of $\alpha$-amylase from Bacillus licheniformis ATCC 6346; in the presence of $0.1 \mathrm{M} \mathrm{NaCl}$ $(\circ), 1 \mathrm{mM} \mathrm{Ca}^{2+}(\square)$ and both $0.1 \mathrm{M} \mathrm{NaCl}$ and $1 \mathrm{mM} \mathrm{Ca}^{2+}(\Delta)$ at $85{ }^{\circ} \mathrm{C}$; in presence of $0.1 \mathrm{M} \mathrm{NaCl}(\bullet), 1$ $\mathrm{mM} \mathrm{Ca}{ }^{2+}(\boldsymbol{\theta})$ and both $0.1 \mathrm{M} \mathrm{NaCl}$ and $1 \mathrm{mM} \mathrm{Ca}^{2+}(\boldsymbol{\Delta})$ at $90{ }^{\circ} \mathrm{C}$; and in presence of $0.1 \mathrm{M} \mathrm{NaCl}(\Theta), 1 \mathrm{mM}$ $\mathrm{Ca}^{2+}(\boxminus)$ and both $0.1 \mathrm{M} \mathrm{NaCl}$ and $1 \mathrm{mM} \mathrm{Ca}^{2+}\left(\mathrm{A}\right.$ at $95{ }^{\circ} \mathrm{C}$. 


\section{DISCUSSION}

In the presence of $2 \mathrm{mM} \mathrm{Ca}^{2+}$ and $\mathrm{Na}^{+}$ions separately, $\alpha$-amylase from $B$. licheniformis ATCC 6346 showed higher activity than in the control (which contained no ions) and in the presence of other ions. Therefore, according to our study, $\alpha$-amylase requires $\mathrm{Ca}^{2+}$ and $\mathrm{Na}^{+}$for catalytic activity. A slight inhibition was observed with $\mathrm{Mg}^{2+}$ and $\mathrm{Ba}^{2+}$ and a stronger inhibitory effect was observed with $\mathrm{Cu}^{2+}, \mathrm{Mn}^{2+}$ and $\mathrm{Hg}^{2+}$. The effect of metal ions on the activity of $\alpha$-amylase in Bacillus sp strain KSM-1378, a relative of Bacillus firmus was investigated by Lgarashi et al. (1998) who revealed that $\mathrm{Ni}^{2+}$, $\mathrm{Zn}^{2+}, \mathrm{Cd}^{2+}$ and $\mathrm{Hg}^{2+}$ strongly inhibited the enzyme activity by $82,100,91$ and $100 \%$, respectively. Of the cations, $\mathrm{Na}^{+}, \mathrm{Ca}^{2+}$, and $\mathrm{Mg}^{2+}$, showed stimulatory effect on $\alpha$-amylase of Bacillus licheniformis CUMC 305, whereas $\mathrm{Hg}^{2+}, \mathrm{Cu}^{2+}, \mathrm{Ni}^{2+}, \mathrm{Zn}^{2+}, \mathrm{Ag}^{+}, \mathrm{Fe}^{2+}, \mathrm{Co}^{2+}, \mathrm{Cd}^{2+}$, $\mathrm{Al}^{3+}$ and $\mathrm{Mn}^{2+}$ showed inhibitory effects (Krishnan et al., 1983). $\mathrm{Cu}^{2+}$ has been reported to inhibit the activity of amylases from $B$. circulans (Takasaki, 1982), B. coagulans (Babu et al., 1993) and B. licheniformis (Krishnan et al., 1983). Based on our initial findings on cations, $\mathrm{Ca}^{2+}$ and $\mathrm{Na}^{+}$ions were selected for further investigation to find their effects on the stability of $\alpha$-amylase from $B$. licheniformis ATCC 6346.

Thermal stability of $\alpha$-amylase from $B$. licheniformis is suggested to be due mainly to the additional salt bridges involved with lysine residues (Tomazic et al., 1988). Similarly, the $\alpha$ amylase from $B$. sterothermophilus and mutant $\alpha$-amylase from $B$. amyloliquefaciens have been suggested to be stabilized against thermal denaturation through ionic interactions (Janecek et al., 1992). In our study when the concentration of $\mathrm{Na}^{+}$was increased above $0.1 \mathrm{M}$, the stability of $\alpha$-amylase was decreased. This could be due to the osmotic effect exhibited by high concentrations of $\mathrm{NaCl}$. Accordingly, 0.1 $\mathrm{M} \mathrm{Na}^{+}$was selected to stabilize $\alpha$-amylase from B. licheniformis ATCC 6346. In the presence of $0.1 \mathrm{M} \mathrm{Na}^{+}, \alpha$-amylase showed 1.9 fold increase in half-life than in the presence of $0.4 \mathrm{M} \mathrm{Na}^{+}$at $85^{\circ} \mathrm{C}$. When the pre-incubating temperature was decreased from 85 to $60{ }^{\circ} \mathrm{C}$, the half-life of $\alpha$ amylase containing $0.1 \mathrm{M} \mathrm{Na}^{+}$was increased by 19.6 fold at $\mathrm{pH}$ 7.0. Therefore, $\mathrm{Na}^{+}$improved the stability of $\alpha$-amylase. However, $0.1 \mathrm{M} \mathrm{Na}^{+}$ could not continue to keep the $\alpha$-amylase in the active state at higher temperatures, above $70{ }^{\circ} \mathrm{C}$. This could be due to the breakdown of the $\mathrm{Na}^{+}-$ $\alpha$-amylase bond with the increase in temperature.
It can be concluded that $\mathrm{Ca}^{2+}$ ions improved the stability of $\alpha$-amylase from $B$. licheniformis ATCC 6346. At liquefying temperatures (90-100 ${ }^{\circ} \mathrm{C}$ ), commercially used amylases require $\mathrm{Ca}^{2+}$ as a stabilizer (Kumar et al., 1990). Since $1.0 \mathrm{mM}$ $\mathrm{Ca}^{2+}$ improved the stability of $\alpha$-amylase it was selected for further investigation of the stability of $\alpha$-amylase with temperature. Since $\mathrm{Ca}^{2+}$ increased the stability of $\alpha$-amylase it could be concluded that this enzyme is a calcium dependant $\alpha$-amylase. $\alpha$-amylase from $B$. licheniformis is far more thermostable than the $\alpha$-amylases produced by other Bacillus species (Declerck et al., 2002). Presence of $\mathrm{Ca}^{2+}$ ions showed positive effect on the thermostability of amylolytic enzymes, including the amylases from B. licheniformis (Violet et al., 1989), Pyrococcus furiosus (Dong et al., 1997), Thermococcus litoralis (Brown et al., 1993) and $\alpha$-amylase from $B$. amyloliquefaciens, leading to increased stability (Farez-Vidal et al., 1995).

It is evident from this study that the metal ions such as $\mathrm{Ca}^{2+}$ and $\mathrm{Na}^{+}$increase the stability of the $\alpha$-amylase from $B$. licheniformis ATCC 6346. The half-life of $\alpha$-amylase from $B$. licheniformis ATCC 6346 at 75 and $85{ }^{\circ} \mathrm{C}$ was 203.2 and 13.8 min respectively at $\mathrm{pH}$ 7.0. $\alpha-$ amylase from Bacillus subtilis AX20 showed 60 and $35 \%$ of maximum activity at 40 and $70{ }^{\circ} \mathrm{C}$, respectively, and stability at $50^{\circ} \mathrm{C}$ for $45 \mathrm{~min}$ (Mohsen et al., 2005). Temperature stable $\alpha$ amylase from Bacillus licheniformis 584 rapidly lost its activity at temperatures above $76{ }^{\circ} \mathrm{C}$ (Saito and Yamamoto, 1975).

Since $\mathrm{Ca}^{2+}$ and $\mathrm{Na}^{+}$ions when used separately improved the stability of $\alpha$-amylase from B. licheniformis ATCC 6346, combined effect of these two ions on $\alpha$-amylase stability at different temperature were studied. Presence of $\mathrm{Ca}^{+}$and $\mathrm{Na}^{+}$ions together increased the stability of $\alpha$-amylase more than when they were present alone. Therefore, this supported the previous hypothesis that these two ions form linkages with $\alpha$-amylase. Of these two ions, $\mathrm{Ca}^{2+}$ ions stabilized the enzyme more than $\mathrm{Na}^{+}$ions. Calcium has a direct role in increasing the stability of $\alpha$-amylases from $B$. licheniformis ATCC 6346. When the temperature was increased from 85 to $95{ }^{\circ} \mathrm{C}$, the stability of $0.1 \mathrm{M}$ $\mathrm{Na}^{+}$and $1 \mathrm{mM} \mathrm{Ca}{ }^{2+}$ containing $\alpha$-amylase was reduced. Hence, it is inferred that high temperatures disturb the bonds formed between $\mathrm{Ca}^{2+}$ and $\mathrm{Na}^{+}$ions and the enzyme. In addition to protein stabilization (Feller et al., 1999), $\mathrm{Ca}^{2+}$ has been reported to exhibit roles in allosteric activation (Feller et al., 1994). 
The findings indicate that the $\alpha$-amylase produced by $B$. licheniformis ATCC 6346 possesses properties of an industrial enzyme. Presence of $\mathrm{Ca}^{2+}$ increases the activity and stability of the enzyme. $\mathrm{Na}^{+}$also enhances the activity and stability of the enzyme, but the influence of $\mathrm{Na}^{+}$was less than $\mathrm{Ca}^{2+}$. Combined addition of $\mathrm{Na}^{+}$and $\mathrm{Ca}^{2+}$ increased the enzyme stability at high temperatures. Its moderate salt tolerance and thermostable property makes this enzyme a potential candidate to be employed in applications requiring salt concentrations and stress containing processes.

\section{ACKNOWLEDGEMENTS}

The authors thank Sida/ SAREC and International Science Programme in Chemical Sciences, Sweden for the financial support.

\section{REFERENCES}

Asgher, M., Asad, M.J., Rahman, S.U. and Legge, R.L. (2007). A thermostable amylase from a moderately thermophilic Bacillus subtilis strain for starch processing. Journal of Food Engineering 79: 950-955.

Babu, K.R. and Sathyanarayana, T. (1993). Extracellular calcium inhibited $\alpha$-amylase of Bacilus Cougulans B49. Enzyme Microbiology Technology 15: 1066-1069.

Boel, E., Brady, L., Brzozowski, A.M., Derewenda, Z., Dodson, G.G., Jensen, V.J., Petersen, S.B., Swift, H., Thim, L. and Woldike, H.F. (1990). Calcium binding in $\alpha-$ amylase: an X-ray diffraction study at 2.1-A resolution of two enzymes from Aspergillus. Biochemistry 29: 6244-6249.

Brown, S. H. and Kelly, R.M. (1993). Characterization of Amylolytic Enzymes, Having Both $\alpha-1,4$ and $\alpha-1,6$ Hydrolytic Activity, from the Thermophilic Archaea Pyrococcus furiosus and Thermococcus litoralis. Applied and Environmental Microbiology 59: 2614-2621.

Chiang, J.P., Alter, J.E. and Sternberg-Elkhart, M. (1979). Purification and characterization of thermostable $\alpha$-amylase from Bacillus licheniformis. Starch/Strake 31:86-92.

Cordeiro, C. A. M., Martinas, M. L. L. and Lucaino, A. (2003). Production and Properties of $\alpha$-amylase from thermophylic Bacillus species. Brazilian Journal of Microbiology 33:1-3.

Declerck, N., Machius, M., Joyet, P., Wiegand, G., Huber, R. and Gaillardin, C. (2002).
Engineering the thermostability of Bacillus licheniformis $\alpha$-amylase. Biologica 57: 203211.

Dong, G., Vieille, C., Savchenko, A. and eikus, J.G. (1997). Cloning, sequencing and expression of the gene encoding extracellular $\alpha$-amylase from Pyroccus furiosus and biochemical characterization of the recombinant enzyme. Applied Environmental Microbiology 63: 3569-3576.

Eke, O. S., and Oguntimehin, G. B. (1992). Partial purification and characterization of alpha amylase from Bacillus cereus. Journal of Agricultural Science and Technology 2(2):152-157.

Farez-Vidal, M.E, Femandez-Vivas, A., Gonzalez, F. and Arias, J.M. (1995). Properties and significance of an alphaamylase produced by Myxococcus coralloides D. Journal of Applied Biotechnology 78: 14-19.

Feller, G., d'Amico, D. and Gerday, C., (1999). Therrmodynamic stability of cold active $\alpha$ amylase from the antratic bacterium Alteromonas haloplantics. Biochemistry 38:4613-4619.

Feller, G., Payan, F., Theys, F., Qian, M., Haser, R. and Gerday, C (1994). Stability and structural analysis of $\alpha$-amylase from the Antratic Psychrophile Alteromonas haloplantis A 23. Europian Journal of Biochemistry 222: 441-447.

Gregory, A.T., and Woods, L. F. J. (1995). Enzymes in food processing, second ed., Blackie Academic \& Professional: pp. 250257.

Hagihara, H., Kazuki, I., Yasuhiro, H., Endo, K., Ikawa-Kitayama, K., Ozaki, K., Kawai, S., Ito, S. (2001). Novel $\alpha$-amylase that is highly resistant to chelating reagents and chemical oxidants from the alkaliphilic Bacillus isolate KSM-K38. Applied Environmental Microbiology 67: 1744-1750.

Janecek, S. and Balaz, S. (1992). $\alpha$-Amylase and approaches leading their enhanced stability. FEBS Letters 304: 1-3.

Kim, K.H., Suh, S.W. and Choi, M.U. (1991). Spectroscopic and Electrophoretic Studies on Structural Stability of alpha-Amylase from Bacillus amyloliquefaciens. Korean Journal of Biochemistry 24: 158-167.

Kobayashi, T., Kanai, H., Hayashi, T., Akiba, T., Akaboshi, R. and HoriKoshi, K. (1992). Haloalkaliphilic maltotriose-forming $\alpha$ amylase from the archaeobacterium Natronococcus sp. Strain Ah-36. Journal of Bacteriology 174:3439-3444. 
Krishnan, T. and Chandra, A.K. (1983). Purification and characterization of alphaamylase from Bacillus licheniformis CUMC305. Appied Enviornmental Microbiology 46:430-437.

Kumar, S. U., Rehana, F. and Nand, K. (1990). Production of an extracellular thermostable calcium-inhibited $\alpha$-amylase by Bacillus licheniformis MY 10. Enzyme and Microbial Technology 12:714-716.

Lecker, D.N. and Khan, A. (1996). Theoretical and experimental studies of the effects of heat, EDTA, and enzyme concentration on the inactivation rate of $\alpha$-amylase from Bacillus sp. Biotechnology Progress 12: 713717.

Lgarashi, K., Hatada, Y. and Hagihara, H. (1998). Enzyme properties of a novel liquefying $\alpha$-amylase from an alkaliphilic Bacillus isolate and entire nucleotide and amino acid sequences. Applied Environmental Microbiology 64(9): 32823289.

Machius, M., Declerck, N., Huber, R. and Wiegand, G. (1998) Activation of Bacillus licheniformis $\alpha$-amylase through a disorderorder transition of the substrate-binding site mediated by a calcium-sodium-calcium metal triad. Structure 6: 281-292.

Machius, M., Wiegand, G. and Hubber, R., (1995) Crystal structure of calcium depleted Bacillus licheniformis $\alpha$-amylase at $2.2 \mathrm{~A}$ resolution. Journal of Molecular Biology 246: 545-559.

Miller, G. (1959). Use of dinitrosalisilic reagent for the determination of reducing sugars. Analitical Chemistry 31: 426-428.

Mohsen, F. J., Dileep, D. and Deepti, D. (2005). Purification and characterization of an extracellular $\alpha$-amylase from Bacillus subtilis AX20. Protein Expression and Purification 41: 349-354.

Niehaus, F., Bertoldo, C., Kahler, M. and Antranikian, G. (1999). Extremophiles as a source of novel enzymes for industrial application, Applied Microbiology Biotechnology 51: 711-729.
Nonaka, T., Fujihashi, M., Kita, A., Hagihara, H., Ozaki, K., Ito, S. and Miki, K. (2003) Crystal structure of calcium-free $\alpha$-amylase from Bacillus sp. Strain KSM-K38 (AmyK38) and its sodium ion binding sites. Journal of Biological Chemistry 278: 2481824824.

Pandey, A., Nigam, P., Soccol, C.R, Soccol, V.T., Singh, D. and Mohan, R. (2000). Advances in microbial amylases. Biotechnology Applied Biochemistry 31: 135152.

Saito, N and Yamamoto, K. (1975). Regulatory factors affecting $\alpha$-amylase production in $B$. licheniformis. Journal of Bacteriology 121: 848-856.

Swain, M.R. and Ray, R. C. (2007). Alpha amylase production by $B$. subtilis $\mathrm{CM} 3$ in solid state fermentation using cassava fibrous residue. Journal of Basic Microbiology 47: 417-425.

Takasaki, Y. (1982). Production of maltohexaose by $\alpha$-amylase from Bacillus circulans G6. Agricultural and Biological Chemistry 46: 1539-1547.

Tanaka, A. and Hoshino, E. (2002). Calciumbinding parameter of Bacillus amyloliquefaciens $\alpha$-amylase determined by inactivation kinetics. Biochemistry Journal 364: 635-639.

Tomazic, S.J. and Klibanov, A. (1988). Why is one Bacillus $\alpha$-amylase more resistant against irreversible thermoinactivation than another? Journal of Biological Chemistry 263: 30923096.

Vihinen, M. and Mantsala, P. (1990). Characterization of thermostable Bacillus sterothermophillus $\alpha$-amylase. Biotechnology Applied Biochemistry 12: 427-435.

Violet, M. and Meunier, J.C. (1989). Kinetic study of the irreversible thermal denaturation of Bacillus licheniformis $\alpha$-amylase. Biochemistry Journal 263: 665-670. 